\title{
Metallentfernung von eingeschobenen Platten mit „alten“ Küntscher-Nagel-Ausziehhaken
}

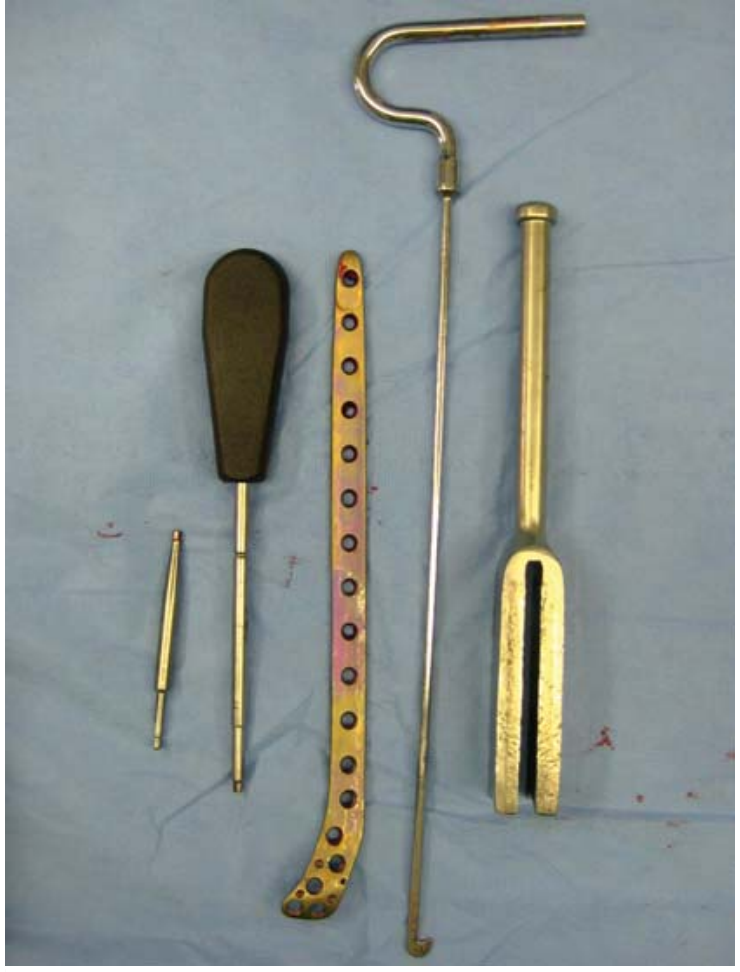

-Abb. 1 „Altes“ Küntscherhaken-Instrumentarium. Glbt es wahrscheinlich noch in Ihrem Op.

Manchmal ist es schwierig, eingeschobene Platten herauszuziehen, wenn alle Schrauben entfernt sind.

Entweder man verwendet Einzinkerhaken, eine andere Möglichkeit ist, mit einem Hebelinstrument einmal rechts und links herum zu hebeln, um Knochenbrücken zu knacken.

Ein weiterer gut funktionierender Trick ist:

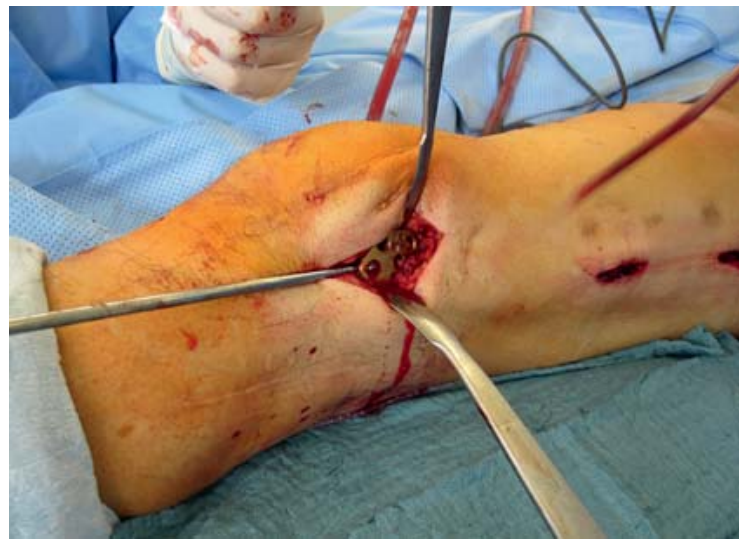

- Abb. 2 Einhängen des Hakens

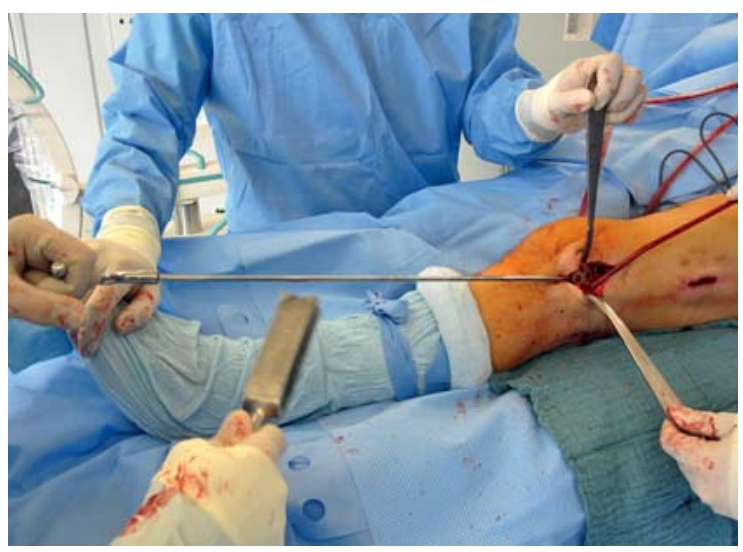

- Abb. 3 Der Schlitzhammer überträgt die Kraft optimal und damit auch schonend für Patient und Arzt

Ein alter Ausziehhaken von der Küntschernagelung ( $\vee$ Abb. 1) wird in das erste Loch eingehängt ( $>$ Abb. 2). Dann wird mit dem Schlitzhammer angeschlagen ( $\bullet$ Abb. 3). Dabei sollte der Griff des Hakens vom Bauch 


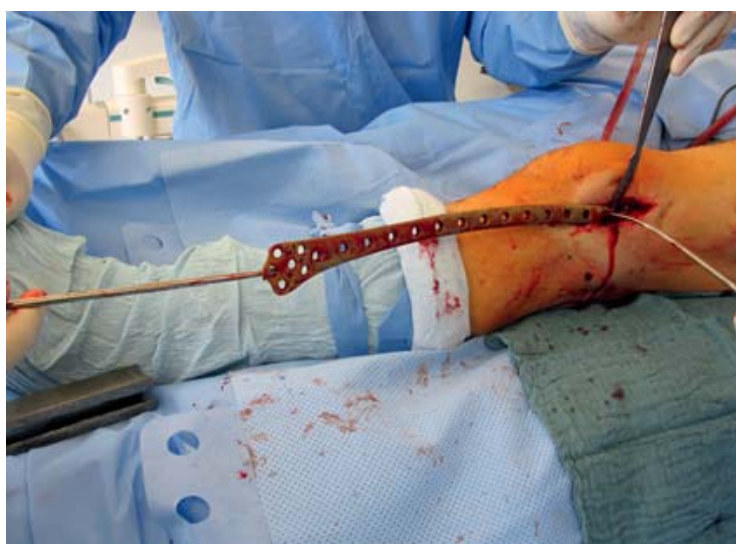

des Operateurs gegengehalten werden, damit beim ersten Anschlag nur ein kleiner Knacks entsteht. Das weitere Ausziehen/vorsichtig Ausschlagen geht dann einfacher ( Abb. 4) .

Korrespondenzadresse

Prof. Dr. Dankward Höntzsch

Tübingen

hoentzsch@t-online.de

- Abb. 4 Geschafft... 